\title{
Various Options for Removal of Fluoride from Drinking Water
}

\author{
Neelo Razbe ${ }^{1}$, Rajesh Kumar ${ }^{2}$, Pratima ${ }^{3}$ and Rajat Kumar ${ }^{4}$ \\ ${ }^{1}$ Reseach Scholar of Singhania University, Jhunjhunu Rajasthan, India \\ ${ }^{2}$ Department of Chemical Engg. HBTI Kanpur, India \\ ${ }^{3,4}$ Department of Chemistry DAV-PG College Kanpur, India
}

\begin{abstract}
Excessive fluoride concentrations have been reported in groundwaters of more than 20 developed and developing countries including India where 19 states are facing acute fluorosis problems. Various technologies are being used to remove fluoride from water but still the problem has not been rooted out. In this paper, a broad overview of the available technologies for fluoride removal and advantages and limitations of each one have been presented based on literature survey and the experiments conducted in the laboratory with several processes. It has been concluded that the selection of treatment process should be site specific as per local needs and prevailing conditions as each technology has some limitations and no one process can serve the purpose in diverse conditions.
\end{abstract}

Keywords: Fluoride; Fluorosis; Ground water; Soil water; Drinking water; Treatment

\section{Introduction}

The fluoride occurs mainly as sellaite $(\mathrm{MgF} 2)$, fluorspar $(\mathrm{CaF} 2)$, cryolite $(\mathrm{Na} 3 \mathrm{AlF} 6)$ and fluorapatite [3Ca3(PO4)2 $\mathrm{Ca}(\mathrm{F}, \mathrm{Cl} 2)]$. As fluorspar it is found in sedimentary rocks and as cryolite in igneous rocks. These fluoride minerals are nearly insoluble in water. Hence fluorides will be present in groundwater only when conditions favour their dissolution or high fluoride containing effluents are discharged to the water bodies from industries.

Fluoride in drinking water has a profound effect on teeth and bones. Fluoride displaces hydroxide ions from hydroxyapatite, $\mathrm{Ca} 5$ ( $\mathrm{PO} 4) 3 \mathrm{OH}$, the principal mineral constituent of teeth (in particular the enamel) and bones, to form the harder and tougher fluoroapatite, $\mathrm{Ca} 5$ (PO4)3F. Up to a small level this strengthens the enamel. However, fluoroapatite is an order of magnitude less soluble than hydroxyapatite, and at high fluoride concentration the conversion of a large amount of the hydroxyapatite into fluoroapatite makes the teeth and (after prolonged exposure) the bones denser, harder and more brittle. In the teeth this causes mottling and embrittlement, a condition known as dental fluorosis. With prolonged exposure (Dissanayake, $1991^{1}$ ) at higher fluoride concentrations dental fluorosis progresses to skeletal fluorosis (Table 1). Fluoride is thus considered beneficial in drinking water at levels of about $0.7 \mathrm{mg} / \mathrm{L}$ but harmful once it exceeds $1.5 \mathrm{mg} / \mathrm{L}$ which is the World Health Organisation limit being followed in most of the nations $\left(\mathrm{WHO}^{2}, 1985\right.$; Smet, $\left.1990^{3}\right)$ and is also the Australian recommended limit (NHMRC, 2004 ${ }^{4}$ ). The difference between desirable doses and toxic doses of fluoride is ill-defined, and fluoride may therefore be considered as an essential mineral with a narrow margin of safety $\left(\mathrm{WHO}^{5}, 1984\right)$.

Table 1

Effect of prolonged use of drinking water on human health, related to fluoride content (Dissanayake ${ }^{1}$, 1991).

\begin{tabular}{|l|l|}
\hline F_1 concentration, $\mathrm{mg} / \mathrm{L}$ & Health outcome \\
\hline$<0.5$ & Dental caries \\
\hline $0.5-1.5$ & Optimum dental health \\
\hline $1.5-4.0$ & Dental fluorosis \\
\hline $4.0-10$ & Dental and skeletal fluorosis \\
\hline$>10.0$ & Crippling fluorosis \\
\hline
\end{tabular}

With the increase in industrial activities water bodies with excess levels of fluoride are becoming a matter of great concern. High fluoride concentrations in groundwater, up to more than $30 \mathrm{mg} / \mathrm{L}$, occur widely, notably in the United States of America, Africa and Asia (Czarnowski et al. ${ }^{6}, 1996$; Azbar and Turkman ${ }^{7}, 2000$; Wang et al ${ }^{8}$., 2002; Agarwal et $\mathrm{al}^{9}$., 2003; Moges et $\mathrm{al}^{10}{ }^{10}$, 1996; Gaciri and Davies ${ }^{11}$, 1992; Chernet et al ${ }^{12}$., 2002; Mjengera and Mkongo ${ }^{13}$, 2002; Moturi et al ${ }^{14}$., 2002; Apambire et al ${ }^{15}$., 1997). Long back it was estimated $\left(\mathrm{WHO}^{5}, 1984\right)$ that more than 260 million people worldwide consume drinking water with a fluoride content of $>1.0 \mathrm{mg} / \mathrm{L}$. The majority of these people live in tropical countries where the problem is exacerbated by the need to drink more water because of the heat. It is thus absolutely essential to bring down the fluoride levels to 
acceptable limits for which tremendous research and development efforts are being put all over the world. The present paper reviews the techniques available and ongoing efforts for fluoride removal from drinking water.

\section{Occurrence and sources}

Fluoride in minute quantity is an essential component for normal mineralization of bones and formation of dental enamel [16]. However, its excessive intake may result in slow, progressive crippling scourge known as fluorosis. There are more than 20 developed and developing nations that are endemic for fluorosis. These are Argentina, U.S.A., Morocco, Algeria, LibyaEgypt, Jordan, Turkey, Iran, Iraq, Kenya, Tanzania, S. Africa, China, Australia, New Zealand, Japan, Thailand, Canada, Saudi Arabia, Persian Gulf, Sri Lanka, Syria, India, etc. [17]. In India, itwas first detected in Nellore district of Andhra Pradesh in 1937 [18].

\subsection{Fluoride-related health effects}

A total of 17 (out of 32) States are reported to have endemic fluorosis in India $\left(\right.$ FRRDF $^{19}, 1999$; Yadav et $\mathrm{al}^{20}$., 1999). In 1987, it was estimated that 25 million people were suffering from fluorosis (FRRDF ${ }^{19}, 1999$ ).

\subsection{Dental fluorosis}

The prevalence of dental fluorosis has been investigated in Rajasthan by Choubisa et $\mathrm{al}^{21}$. (1997). Prevalence rates were observed in 15 tribal villages with fluoride concentrations of $0.3-10.8 \mathrm{mg} \mathrm{l}-1$. At mean fluoride concentrations of 1.4 and $6 \mathrm{mg} 1-1$, dental fluorosis was seen in 25.6 per cent and 84.4 per cent of school children (<16 years) and 23.9 per cent and 96.9 per cent of adults respectively. Kodali et $\mathrm{al}^{22}$. (1994) reported dental mottling in 76 per cent of children in the 5-10 year age group and 84 per cent of children in the $10-15$ year age group in Kodabakshupally, Sarampet and Sivannagudem. Yadav and Lata ${ }^{23}$ (2003) examined the prevalence of dental fluorosis at lower drinking-water fluoride concentrations (mean concentrations between 1.93 and $2.14 \mathrm{mg} \mathrm{1-1)}$ in the Jhajjar district, Haryana. Over 50 per cent of the children examined were found to be affected by dental fluorosis. Reddy and Prasad ${ }^{24}(2003)$ reported dental fluorosis levels of 43 per cent in the Anantapur district of Andhra Pradesh, where drinking- water fluoride concentrations ranged between 1.2 and 2.1 mg $1-1$.

\subsection{Skeletal fluorosis}

Endemic skeletal fluorosis was reported from India in the 1930s. It was observed first in Andhra Pradesh bullocks used for ploughing, when farmers noticed the bullocks inability to walk, apparently due to painful and stiff joints. Several years later the same disease was observed in humans (Short et $\mathrm{al}^{25}, 1937$ ). Choubisa et al. (1997) examined the prevalence of skeletal fluorosis in Rajasthan in adults exposed to mean fluoride levels of 1.4 and $6 \mathrm{mg} \mathrm{l}-1$. At $1.4 \mathrm{mg} \mathrm{1-1}$ over 4 per cent of adults were reported to be affected, while at $6 \mathrm{mg} \mathrm{1-1,63}$ per cent of adults were reported to be affected. The prevalence was found to be higher in males and increased with increasing fluoride levels and age. In Andhra Pradesh, Reddy and Prasad (2003) found skeletal fluorosis affecting between 0.2 and 1 per cent of the population examined, where the maximum drinking-water fluoride concentration was $2.1 \mathrm{mg} 1-1$.

\subsection{Exposure, fluorosis and fluoride concentrations}

At least 17 States are affected by elevated fluoride levels in drinking-water, namely; Andhra Pradesh, Assam, Bihar, Delhi, Gujarat, Haryana, Jammu and Kashmir, Kamataka, Kerala, Madhya Pradesh, Maharashtra, Orissa, Punjab, Country Data 105 Rajasthan, Tamil Nadu, Uttar Pradesh and West Bengal. These have been progressively identified since the first report by Short et $\mathrm{al}^{23}$. (1937), with Assam being the most recently identified State with high fluoride levels associated with endemic fluorosis. Not all States are equally affected and the number of districts with endemic fluorosis within each State varies (FRRDF, 1999). Nine out of eighteen districts in West Bengal were recently identified as having fluoride contaminated groundwater (Ministry of Water Resources ${ }^{26}$, 2004). It has been estimated that the total population consuming drinking-water containing elevated levels of fluoride is over 66 million (FRRDF, 1999). The distribution of fluoride in Indian ground waters is shown in Table 2.

In Rajasthan, fluoride concentrations have been found to vary between $0.6 \mathrm{mg} 1-1$ and $69.7 \mathrm{mg} \mathrm{l-1}$ $\left(\mathrm{Gupta}^{2}, 1999\right)$. In Haryana, the highest fluoride concentration was found in the village of Karoli and was recorded at $48 \mathrm{mg} \mathrm{l-1}$ (Kim-Farley, pers. com.). Meenakshi et $\mathrm{al}^{28}$. (2004) reported fluoride levels of between 0.3 and $6.9 \mathrm{mg} 1-1$ in four villages in the Jind district of Haryana. 
Table 2 Fluoride concentrations reported in ground waters of India

\begin{tabular}{|l|l|l|}
\hline Region/State & $\begin{array}{l}\text { Fluoride concentration } \\
\text { (mg l-1) }\end{array}$ & $\begin{array}{l}\text { Maximum severity of } \\
\text { fluorosis observed }\end{array}$ \\
\hline North-West India & $0.4-19$ & Severe \\
\hline Central India & $0.2-10$ & Moderate \\
\hline South India & $0.2-20$ & Severe \\
\hline Deccan Province & $0.4-8$ & Moderate \\
\hline
\end{tabular}

Sources: Agarwal et al. (1997); Yadav et al. (1999)

\subsection{Mitigation measures}

Formal mitigation measures were undertaken from 1987, when the Government of India made a commitment to provide safe water to the rural community (i.e. those most affected by fluorosis). Since 1987, numerous programmes aimed at fully identifying the problem, along with developing fluoride removal techniques have been implemented (FRRDF, 1999). In the Dungarpur district of Rajasthan, activated alumina and Nalgonda defluoridation are practised. Defluoridation kits have been distributed at household level under thesponsorship of UNICEF and active community participation has been observed with the result that it has been reported that the ongoing Fluorosis Mitigation Programme is sustainable (Vaish and Vaish ${ }^{29}, 2000$ ). In Andhra Pradesh the use of check dams, to dilute fluoride concentrations in groundwater, has been investigated (Bhagavan and Raghu ${ }^{30}$, 2005). The check dams, which are rainwater harvesting structures, are designed to provide artificial recharge of groundwater. In over 50 per cent of cases, the check dams were found to reduce fluoride concentrations in groundwater.

\subsection{Other problems}

This aspect of fluorosis is often overlooked because of the notion prevailing that fluoride only affects bones and teeth. Besides skeletal and dental fluorosis, excessive consumption of fluoride may lead to muscle fibre degeneration, lowhaemoglobinlevels, deformities in RBCs, excessive thirst, headache, skin rashes, nervousness, neurological manifestations (it affects brain tissue similar to the pathological changes found in humans with Alzheimer's disease), depression, gastrointestinal problems, urinary tract malfunctioning, nausea, abdominal pain, tingling sensation in fingers and toes, reduced immunity, repeated abortions or still births, male sterility, etc. It is also responsible for alterations in the functional mechanisms of liver, kidney, digestive system, respiratory system, excretory system, central nervous system and reproductive system, destruction of about 60 enzymes. The effects of fluoride in drinking water on animals are analogous to those on human beings. The continuous use of water having high fluoride concentration also adversely affects the crop growth.

\section{Various Options For Removal Of Fluoride}

A community with excessive fluoride in its water supply may meet the local MCL in one or more of several ways. Fluoride poisoning can be prevented or minimized by:

1. Using alternate water sources.

2. By improving the nutritional status of population at risk.

3. By removing excess fluoride (defluoridation).

\subsection{Alternate water sources}

Alternate water sources include surface water, rainwater and low-fluoride groundwater. Since surface water is often heavily contaminated with biological and chemical pollutants, it cannot be used for drinking purposes without treatment and disinfection making it too expensive and complex for application in poor communities. Rainwater is usually a much cleaner water source and may provide a low-cost simple solution. The problem however is its uneven distribution limited storage capacity in communities or households. The fact that fluoride is unevenly distributed in groundwater and its concentration keeps on changing with time both vertically and horizontally, implies that every well has to be tested individually and regular monitoring has to be done, which is not always possible in rural areas. Thus the option of using alternate water sources has its own limitations.

\section{3..2. Better nutrition}

Clinical data indicate that adequate calcium intake is directly associated with a reduced risk of dental fluorosis [31]. Vitamin C also safeguards against the risk [32]. Though, measures to improve the nutritional status of an affected population might be an effective supplement to the technical solutions of the problem, practically it sounds non-feasible. 


\subsection{Defluoridation of water}

Defluoridation of drinking water is the only practicable option to overcome the problem of excessive fluoride in drinking water, where alternate source is not available. During the years following the discovery of fluoride as the cause of fluorosis, extensive research has been done on various methods for removal of fluoride from water and wastewater. These methods are based on the principle of adsorption [33], ion-exchange[34], precipitation-coagulation [35,36], membrane separation process [37,38], electrolytic defluoridation [39], electrodialysis [40-42], etc.

\section{3..3.1. Adsorption.}

Several adsorbent materials have been tried in the past to find out an efficient and economical defluoridating agent. Activated alumina, activated carbon, activated alumina coated silica gel, calcite, activated saw dust, activated coconut shell carbon and activated fly ash, groundnut shell,coffee husk, rice husk, magnesia, serpentine, tricalcium phosphate, bone charcoal, activated soil sorbent, carbion, defluoron- 1, defluoron-2, etc., are different adsorbent materials reported in the literature [43-51]. The most commonly used adsorbents are activated alumina and activated carbon. The fluoride removing efficiency of activated alumina gets affected by hardness and surface loading (the ratio of total fluoride concentration to activated alumina dosage). Chloride does not affect the defluoridation capacity of activated alumina. The process is $\mathrm{pH}$ specific, so $\mathrm{pH}$ of the solution should be between 5.0 and 6.0 because at $\mathrm{pH}>7$, silicate and hydroxide become stronger competitor of the fluoride ions for exchange sites on activated alumina and at $\mathrm{pH}$ less than 5, activated alumina gets dissolved in acidic environment leading to loss of adsorbing media [52]. The process is highly selective but it has low adsorption capacity, poor physical integrity, requires acidification and pretreatment and its effectiveness for fluoride removal reduces after each regeneration. Mckee and Johnston 1934, investigated the use of powdered activated carbon for fluoride removal and achieved good results [53]. The process is $\mathrm{pH}$ dependent with good results only at $\mathrm{pH} 3.0$ or less. Therefore, the use of this material is expensive due to need of $\mathrm{pH}$ adjustment. Activated alumina technique for defluoridation is being propagated in several villages by the voluntary organizations funded by UNICEF or other agencies to provide safe drinking water. Sarita Sansthan, Udaypur, Rajasthan is disseminating the technique with the practical assistance of UNICEF by providing a bucket (approximately $20 \mathrm{~L}$ capacity) fitted with a microfilter at the bottom containing $5 \mathrm{~kg}$ of activated alumina.

\section{3..3.1.1. Advantages.}

- The process can remove fluoride up to $90 \%$.

- Treatment is cost-effective.

\section{3..3.1.2. Limitations.}

- The process is highly dependent on $\mathrm{pH}$ and works best only in a narrow $\mathrm{pH}$ range (5-6).

- High concentration of total dissolved salts (TDS) can result in fouling of the alumina bed.

- Presence of sulfate, phosphate or carbonate results in ionic competition.

- The process has low adsorption capacity, poor integrity and needs pretreatment.

- The regeneration is required after every 4-5 months and effectiveness of adsorbent for fluoride removal reduces after each regeneration.

- Disposal of fluoride laden sludge and concentrated regenerant is also a problem.

\subsubsection{Ion-exchange.}

Fluoride can be removed from water supplies with a strongly basic anion-exchange resin containing quarternary ammonium functional groups. The removal takes place according to the following reaction:

Matrix-NR3 $+\mathrm{Cl}-+\mathrm{F}-\rightarrow$ Matrix-NR3 $+\mathrm{F}-+\mathrm{Cl}-$

. The fluoride ions replace the chloride ions of the resin. This process continues until all the sites on the resin are occupied. The resin is then backwashed with water that is supersaturated with dissolved sodium chloride salt. New chloride ions then replace the fluoride ions leading to recharge of the resin and starting the process again. The driving force for the replacement of chloride ions from the resin is the stronger electronegativity of the fluoride ions

3..3.2.1. Advantages.

- Removes fluoride up to $90-95 \%$.

- Retains the taste and colour of water intact.

\subsubsection{Limitations.}

- Efficiency is reduced in presence of other ions like sulfate, carbonate, phosphate and alkalinity.

- Regeneration of resin is a problem because it leads to fluoride rich waste, which has to be treated separately before final disposal.

- The technique is expensive because of the cost of resin, pretreatment required to maintain the $\mathrm{pH}$, regeneration andwaste disposal.

- Treated water has a very low $\mathrm{pH}$ and high levels of chloride. 


\subsubsection{Coagulation-precipitation}

Lime and alum are the most commonly used coagulants. Addition of lime leads to precipitation of fluoride as insoluble calcium fluoride and raises the $\mathrm{pH}$ value of water upto 11-12.

$\mathrm{Ca}(\mathrm{OH}) 2+2 \mathrm{~F}-\rightarrow \mathrm{CaF} 2+2 \mathrm{OH}-$

As lime leaves a residue of $8.0 \mathrm{mg} \mathrm{F}-/ \mathrm{L}$, it is used only in conjunction with alum treatment to ensure the proper fluoride removal [54-56]. As a first step, precipitation occurs by lime dosing which is followed by a second step in which alum is added to cause coagulation. When alum is added to water, essentially two reactions occur. In the first reaction, alum reacts with some of the alkalinity to produce insoluble aluminium hydroxide $[\mathrm{Al}(\mathrm{OH}) 3]$. In the second reaction, alum reacts with fluoride ions present in the water. The best fluoride removal is accomplished at $\mathrm{pH}$ range of 5.5-7.5 [57].

\subsubsection{Advantages.}

- The Nalgonda technique of defluoridation is based on combined use of alum and lime in a two-step process and has been claimed as the most effective technique for fluoride removal• Under Rajiv Gandhi DrinkingWater Mission, several fill and draw (F\&D) type and handpump attached (HPA) plants based on Nalgonda technique have come up in rural areas for which design and technology has been developed by NEERI, Nagpur.

\subsubsection{Limitations.}

After having 10 years experience with these plants, the following serious drawbacks have been experienced:

- The process removes only a smaller portion of fluoride (18-33\%) in the form of precipitates and converts a greater portion of ionic fluoride (67-82\%) into soluble aluminium fluoride complex ion, and therefore this technology is erroneous. Also, as the soluble aluminium fluoride complex is itself toxic, adoption of Nalgonda technique for defluoridation of water is not desirable [60].

- Due to use of aluminium sulfate as coagulant, the sulfate ion concentration increases tremendously and in few cases, it crosses the maximum permissible limit of $400 \mathrm{mg} / \mathrm{L}$, which causes cathartic effect in human beings.

- The residual aluminium in excess of $0.2 \mathrm{mg} / \mathrm{L}$ in treated water causes dangerous dementia disease as well as pathophysiological, neurobehavioural, structural and biochemical changes. It also affects musculoskeletal, respiratory, cardiovascular, endocrine and reproductive systems [61].

- Due to organoleptic reasons, users do not like the taste of treated water.

- Regular analysis of feed and treatedwater is required to calculate the correct dose of chemicals to be added, because water matrix keeps on changing with time and season as evident from our earlier studies conducted in laboratory.

- Maintenance cost of plant is very high. On an average as experienced in the recent years, a plant of 10,000 L per day capacity requires Rs. 3000 every month on maintenance.

- The process is not automatic. It requires a regular attendant for addition of chemicals and looking after treatment process.

- Large space is required for drying of sludge.

- Silicates have adverse effect on defluoridation by Nalgonda technique. Temperature also affects the defluoridation capacity.

\section{3..3.4. Membrane process.}

Although various conventional techniques of water purification described earlier are being used at present to solve the problem of groundwater pollution, none of them is user-friendly and cost-effective technique due to some or the other limitation and has either no or very long pay back period. In the recent years, $\mathrm{RO}$ membrane process has emerged as a preferred alternative to provide safe drinking water without posing the problems associated with other conventional methods. RO is a physical process in which the contaminants are removed by applying pressure on the feed water to direct it through a semipermeable membrane. The process is the reverse of natural osmosis as a result of the applied pressure to the concentrated side of the membrane, which overcomes the natural osmotic pressure. RO membrane rejects ions based on size and electrical charge. The factors influencing themembrane selection are cost, recovery, rejection, raw water characteristics and pretreatment. Efficiency of the process is governed by different factors such as raw water characteristics, pressure, temperature and regular monitoring and maintenance, etc. There are two types of membranes that can remove fluoride from water: NF and RO. NF is a relatively low pressure process that removes primarily the larger dissolved solids as compared to RO. Conversely, RO operates at higher pressures with greater rejection of all dissolved solids. Fluoride removal efficiencies upto $98 \%$ by membrane processes have been documented by many researchers. In the past, the use of membrane technology for water treatment, particularly for drinking 
water production had been considered uneconomical in comparison with conventional means, but in the recent years the increased demand and contamination of water, rise in water quality standards and the problems associated with other methods have led to reconsideration of membrane technology for water purification. The progressive technical improvements in design and materials of the membranes have made the water treatment process economically competitive and highly reliable. Also, the capital and operational costs of RO plant go on decreasing with increasing plant capacity [62]. Thus with improved management, this new technology for drinking water production might be the best option. Furthermore, membrane processes present several advantages as compared with other treatment methods [63].

\subsubsection{Advantages.}

- The process is highly effective for fluoride removal. Membranes also provide an effective barrier to suspended solids, all inorganic pollutants, organic micropollutants, pesticides and microorganisms, etc.

- The process permits the treatment and disinfection of water in one step.

- It ensures constant water quality.

- No chemicals are required and very little maintenance is needed.

- Life of membrane is sufficiently long, so problem of regeneration or replacement is encountered less frequently.

- It works under wide $\mathrm{pH}$ range.

- No interference by other ions is observed.

The process works in a simple, reliable automated operating regime with minimal manpower using compact modular model.

\subsubsection{Limitations.}

- It removes all the ions present in water, though some minerals are essential for proper growth, remineralization is required after treatment.

- The process is expensive in comparison to other options.

- The water becomes acidic and needs $\mathrm{pH}$ correction.

- Lot of water gets wasted as brine.

- Disposal of brine is a problem.

- The performance of all the above processes has been tested in the laboratory.Acomparative analysis of the fluoride removal by various processes is presented in Table 5.

\section{Conclusion}

The literature survey and the laboratory experiments have indicated that each of the discussed techniques can remove fluoride under specified conditions. The fluoride removal efficiency varies according to many site-specific chemical, geographical and economic conditions, so actual applications may vary from the generalizations made. Any particular process, which is suitable at a particular region may not meet the requirements at some other place. Therefore, any technology should be tested using the actual water to be treated before implementation in the field.

\section{References}

[1] Dissanayake, C.B., 1991. The fluoride problem in the groundwater of Sri Lanka - environmental management and health. Int. J. Environ. Stud. 19, 195-203.

[2] WHO, 1985. Guidelines for Drinking Water Quality, vol. 3. World Health Organization, Geneva, pp. 1-2.

[3] Smet, J., 1990. Fluoride in drinking water. In: Frencken, LE (Ed.), Endemic Fluorosis in Developing Countries - Causes, Effects and Possible Solution: Report of a Symposium Held in Delft, The Netherlands. Netherlands Organisation for Applied Scientific Research.

[4] NHMRC, 2004. Australian Drinking Water Guidelines. National Health and Medical ResearchCouncil.http://www.nhmrc.gov.au/publications/synopses/ files/adwg_11_06_fact_sheets.pdf.

[5] WHO, 1984. Guidelines for Drinking Water Quality. In: Health Criteria and Other Supporting Information, second ed., vol. 2. World Health Organization, Geneva

[6] Czarnowski, W., Wrzesniowska, K., Krechniak, J., 1996. Fluoride in drinking water and human urine in Northern and Central Poland. Sci. of the Total Environ. 191, 177-184.

[7] Azbar, N., Turkman, A., 2000. Defluoridation in drinking waters. Water Sci. and Technol. 42, $403-407$.

[8] Wang, W.Y., Li, R.B., Tan, J.A., Luo, K.L., Yang, L.S., Li, H.R., Li, Y.H., 2002. Adsorption and leaching of fluoride in soils of China. Fluoride 35, 122-129

[9] Agarwal, M., Rai, K., Shrivastav, R., Dass, S., 2003. Defluoridation of water using amended clay. J. Cleaner Produc. 11, $439-444$.

[10] Moges, G., Zewge, F., Socher, M., 1996. Preliminary investigations on the defluoridation of water using fired clay chips. J. Afr. Earth Sci. 21, 479-482

[11] Gaciri, S.J., Davies, T.C., 1992. The occurrence and geochemistry of fluoride in some natural waters of Kenya. J. Hydrol. 143, 395412.

[12] Chernet, T., Trafi, Y., Valles, V., 2002. Mechanism of degradation of the quality of natural water in the lakes region of the Ethiopian rift valley. Water Res. 35, 2819-2832. 
[13] Mjengera, H., Mkongo, G., 2002. Appropriate defluoridation technology for use in fluorotic areas in Tanzania. 3rd WaterNet Symposium Water Demand Management for Sustainable Development.

[14] Moturi, W.K.N., Tole, M.P., Davies, T.C., 2002. The contribution of drinking water towards dental fluorosis: a case study of Njoro division, Nakuru district, Kenya. Environ. Geochem. and Health 24, 123-130.

[15] Apambire, W.B., Boyle, D.R., Michel, F.A., 1997. Geochemistry, genesis and health implications of fluoriferous groundwaters in the upper regions of Ghana. Environ. Geol. 33, 13-24.

[16] M.C. Bell, T.G. Ludwig, The supply of fluoride to man: ingestion from water, in: Fluorides and Human Health,WHOMonograph Series 59, World Health Organization, Geneva, 1970.

[17] N. Mameri, A.R. Yeddou, H. Lounici, H. Grib, D. Belhocine, B. Bariou, Defluoridation of septentrional Sahara water of North Africa by electrocoagulation process using bipolar aluminium electrodes, Water Res. 32 (5) (1998) 1604-1610.

[18] W.E. Shortt, Endemic fluorosis in Nellore District, South India, Ind. Med. Gazette (1937) $72-396$.

[19] FRRDF 1999 State of Art Report on the Extent of Fluoride in Drinking Water and the Resulting Endemicity in India. Fluorosis Research and Rural Development Foundation, New Delhi.

[20] Yadav, S., Khan, T.I., Gupta, S., Gupta, A.B. and Yadava, R.N. 1999 Fluorosis in India with special reference to Rajasthan. In: Proceedings of the International Conference on Water, Environment, Ecology, Socioeconomics and Health Engineering (WEESHE), Seoul National University, 18-21st October, 3-10.

[21] Choubisa, S.L., Choubisa, D.K., Joshi, S.C. and Choubisa, L. 1997 Fluorosis in some tribal villages of Dungarpur district of Rajasthan, India. Fluoride, 30(4), 223-228.

[22] Kodali, V.R.R., Krishnamachari, K.A.V.R. and Gowrinathsastry, J. 1994 Detrimental effects of high fluoride concentrations in drinking water on teeth in an endemic fluorosis area in South India. Tropical Doctor, 24, 136-137

[23] Yadav, J.P. and Lata, S. 2003 Urinary fluoride levels and prevalence of dental fluorosis in children of Jhajjar District, Haryana. Indian Journal of Medical Science, 57(9), 394-399.

[24] Reddy, N.B. and Prasad, K.S.S. 2003 Pyroclastic fluoride in ground waters in some parts of Tadpatri Taluk, Anantapur district, Andhra Pradesh. Indian Journal of Environmental Health, 45(4), 285-288.

[25] Short, H.E., Pandit, C.G. and Taghavachari, T.N. 1937 Endemic fluorosis in Nellore District of South India. Indian Medical Gazette, 72, 396-398.

[26] Ministry of Water Resources 2004 Contamination of water sources. Press Release of the Government of India, Ministry of Water Resources, Rajya Sabha, Hindustan Times, 8 December 2004

[27] Gupta, S.C. 1999 Occurrence and management of high fluoride ground waters in Rajasthan. In: Proceedings of the National Seminar Fluoride Contamination, Fluorosis and Defluoridation Techniques, Udaipur, 6-9.

[28] Meenakshi, V.K., Garg, Kavita, Renuka and Anju Malik 2004 Groundwater quality in some villages of Haryana, India: focus on fluoride and fluorosis. Journal of Hazardous Materials, 106B, 85-97.

[29] Vaish, A.K. and Vaish, P. 2000 Fluoride contamination, fluorosis and defluoridation at domestic level: a case study from Dungarpur district, Rajasthan, India. In: Proceedings of the third international workshop on fluorosis and defluoridation of water. Chiangmai, Thailand, November 20-24, 2000.

[30] Bhagavan, S.V.B.K. and Raghu, V. 2005 Utility of check dams in dilution of fluoride concentrations in ground water and the resultant analysis of blood serum and urine of villagers, Anantapur district, Andhra Pradesh, India. Environmental Geochemistry and Health, 27, 97-108.

[31] C. Dinesh, Fluoride and human health-cause for concern, Ind. J. Environ. Protec. 19 (2) (1998) 81-89.

[32] Prevention and Control of Fluorosis in India, Rajiv Gandhi National Drinking Water Mission, Manual, 1993.

[33] A.M. Raichur, M.J. Basu, Adsorption of fluoride onto mixed rare earth oxides, Sep. Purif. Technol. 24 (2001) 121-127.

[34] G. Singh, B. Kumar, P.K. Sen, J. Majumdar, Removal of fluoride fromspent pot liner leachate using ion exchange,Water Environ. Res. 71 (1999) 36-42.

[35] S. Saha, Treatment of aqueous effluent for fluoride removal,Water Res. 27 (1993) 1347-1350.

[36] E.J. Reardon, Y. Wang, A limestone reactor for fluoride removal from wastewaters, Environ. Sci. Technol. 34 (2000) $3247-3253$.

[37] Z.Amer, B. Bariou, N. Mameri,M.Taky, S. Nicolas, A. Elmidaoui, Fluoride removal from brackish water by electrodialysis, Desalination 133 (2001) 215-223.

[38] A. Dieye, C. Larchet, B. Auclair, C. Mar-Diop, Elimination des fluorures par la dialyse ionique croisee, Eur. Polym. J. 34 (1998) 67-75.

[39] N. Mameri, H. Lounici, D. Belhocine, H. Grib, D.L. Piron, Y. Yahiat, Defluoridation of Sahara Water by small electrocoagulation using bipolar aluminium electrodes, Sep. Purif. Technol. 24 (2001) 113-119.

[40] M. Hichour, F. Persin, J. Sandeaux, J. Molenat, C. Gavach, Water defluoridation by donann dialysis and electrodialysis, Rev. Sci. Eau 12 (1999) 671-686.

[41] M. Hichour, F. Persin, J. Sandeaux, C. Gavach, Fluoride removal from waters by Donann dialysis, Sep. Purif. Technol. 18 (2000) $1-11$.

[42] S.K. Adhikari, U.K. Tipnis, W.P. Harkare, K.P. Govindan, Defluoridation during desalination of brackish water by electrodialy sis, Desalination 71 (1989) 301-312.

[43] H. Kariyanna, Geological and geochemical environment and causes of fluorosis—possible treatment—a review, in: Proceedings Seminar on Role of Earth Sciences in Environment, Bombay, 1987, pp. 113-122.

[44] J.P. Barbier, P. Mazounie, Methods of reducing high fluoride content in drinking water, Water Supply 2 (1984) SS 8/1-4.

[45] K. Muthukumaran, N. Balasubramanian, T.V. Ramakrishna, Removal of fluoride by chemically activated carbon, Ind. J. Environ. Protec. 15 (7) (1995) 514-517.

[46] W. Rongshu, H. Li, P. Na, W. Ying, Study of a new adsorbent for fluoride removal from waters, Water Qual. Res. J. Can. 30 (1) (1995) 81-88.

[47] Y. Min, T. Hashimoto, N. Hoshi, H. Myoga, Fluoride removal in a fixed bed packed with granular calcite, Water Res. 33 (16) (1999) 3395-3402

[48] Y. Wang, E.J. Reardon, Activation and regeneration of a soil sorbent for defluoridation of drinking water, Appl. Geochem. 16 (2001) 531-539.

[49] C.D. Nava, M.S. Rios, M.T. Olguin, Sorption of fluoride ions from aqueous solutions and well drinking water by thermally heated hydrocalcite, Sep. Sci. Technol. 38 (1) (2003) 131-147.

[50] S. Padmavathy, J. Amali, R.E. Raja, N. Prabavathi, B. Kavitha, A study of fluoride level in potable water of Salem district and an attempt for defluoridation with lignite, Ind. J. Environ. Protec. 23 (11) (2003) 1244-1247.

[51] V.P. Thergaonkar, W.G. Nawalakhe, Activated magnesia for fluoride removal, Ind. J. Environ. Health 16 (1971) $241-243$. 
[52] P.L. Bishop, G. Sansoucy, Fluoride removal from drinking water by fluidized activated alumina adsorption, J. AWWA 70 (1978) $554-559$.

[53] R. Mckee,W.S. Johnston, Removal of fluorides from drinking water using low-cost adsorbent, Ind. J. Environ. Health 41 (1) (1999) 53-58.

[54] D.J. John,Water treatment, Handbook of DrinkingWater Quality Standards and Controls, Van Nostrand Reinhold, New York, pp. 407-490.

[55] R. Culp, H. Stolenberg, Fluoride reduction at La Cross, Kan, J. AWWA 50 (3) (1958) 423-431.

[56] C.L. Parker, C.C. Fong, Fluoride removal technology and cost estimates, Ind. Wastes $23-25$ (1975).

[57] J.H. Potgeiter, An experimental assessment of the efficiency of different defluoridation methods, Chem. SA (1990) 317-318.

[60] B.V. Apparao, G. Kartikeyan, Permissible limits of fluoride on in drinking water in India in rural environment, Ind. J. Environ. Protec. 6 (3) (1986 172-175.

[61] P. Nayak, Review aluminium: impacts and disease, Envtl. Res. Sec. A 89 2002) 101-115.

[62] D. Babra, P. Caputi, D.S. Cifoni, Drinking water supply in Italy, Desalination 113 (1997) 111-117.

[63] Meenakshi, R.C. Maheshwari, S.K. Jain, A. Gupta, Use of membrane technique for potable water production, Desalination 170 (2) (2004) 105- 